\title{
Establishment of a sandwich ELISA for bovine plasma PON-1 and its predictive capabilities for dairy cows with fatty liver
}

\author{
Chang Zhao ${ }^{1}$, Yunlong $\mathrm{Bai}^{2}$, Dong $\mathrm{Wang}^{3}$, and Cheng $\mathrm{Xia}^{2 *}$ \\ ${ }^{1}$ College of Animal Science and Technology, Anhui Agricultural University, Hefei, PR China \\ ${ }^{2}$ College of Animal Science and Veterinary Medicine, Heilongjiang Bayi Agricultural University, Daqing, PR China \\ ${ }^{3}$ Heilongjiang Provincial Key Laboratory of Prevention and Control of Bovine Diseases, College of Animal \\ Scienceand Veterinary Medicine, Heilongjiang Bayi Agricultural University, Sartu District, Daqing, PR China
}

ZHAO, C., Y. BAI, D. WANG, C. XIA: Establishment of a sandwich ELISA for bovine plasma PON-1 and its predictive capabilities for dairy cows with fatty liver. Vet. arhiv 91, 503-512, 2021.

The aim of this study to improve the clinical diagnosis of fatty livers (FL) in dairy cows by using the paraoxonase-1 (PON-1) enzyme as a detection index. Prokaryotic expression technology was used to generate recombinant bovine PON-1 protein. Mice were immunized with this protein to generate hybridoma cells, stably secreting anti-PON-1. Cells were injected into the peritoneal cavity of mice, and ascites were purified to generate bovine PON-1 monoclonal antibody. Rabbits were then immunized with this antigen, and a polyclonal antibody against bovine PON-1 was obtained. Using monoclonal and polyclonal antibodies, a double-antibody sandwich ELISA for plasma PON-1 was constructed. Plasma samples were collected from healthy $(\mathrm{n}=13)$ and FL $(\mathrm{n}=13)$ cows, and plasma PON-1 levels were detected using the PON-1 ELISA. Receiver operating characteristic curve (ROC) analysis was used to analyze correlations between PON-1 levels and FL. Results showed that the ideal working concentration of the monoclonal antibody was $0.8 \mathrm{mg} / \mathrm{mL}$, and the quantitative detection limit was $90 \mathrm{ng} / \mathrm{mL}$. Plasma PON-1 levels were significantly lower in FL cows, when compared with healthy animals. It is concluded that PON-1 ELISA predicts risk factors for dairy cows with FL. PON-1 levels in plasma can be used as an early warning indicator for FL and concentration of $61.87 \mathrm{nmol} / \mathrm{L}$ was identified as warning index.

Key words: clinical applications; ELISA; fatty liver; PON-1; ROC

\section{Introduction}

Currently, fatty liver (FL) is one of the most common nutritional metabolic diseases in intensive dairy cow farming. The incidence in Chinese settings varies widely, and incidence rates as high as $46.2 \%$ have been recorded (YIZHAO et al., 2018). FL has brought huge economic losses to the dairy farming industry; factors associated with FL include a drop in milk yield, and/or the generation of other diseases, such as sputum and postpartum anoestrus (DU and ZHANG, 2018). The international gold standard for diagnosing FL in dairy cows involves liver puncture to assess liver triglyceride levels (MELENDEZ et al., 2018). However, liver puncture has a negative impact on dairy cows, and is a demanding procedure for veterinarians.

\footnotetext{
*Corresponding author:

Cheng Xia, PhD, College of Animal Science and Veterinary Medicine, Heilongjiang Bayi Agricultural University, Daqing, China, Phone: +86138 3696 1128, E-mail: Xcwlxyf2014@163.com
} 
Paraoxonase 1 (PON-1) is a calciumdependent esterase component of plasma high density lipoproteins (HDLs) that hydrolyzes organophosphates and arylesters (VALERIA et al., 2016). Studies in cattle (MIYAMOTO et al., 2005), dogs (MOTTA et al., 2009), cats (TVARIJONAVICIUTE et al., 2005) and horses (RICHTER et al., 2009) have shown that PON-1 levels in plasma may be used as a biomarker to detect a variety of diseases such as diabetes, hyperlipidemia and high cholesterol. Studies have shown that when compared with other periods, decreased PON1 activity in serum at peak milk production is closely related to lipid peroxidation and oxidative stress (KULKA et al., 2014). In addition, PON-1 in milk and blood acts as a biomarker for subclinical mastitis, with a strong correlation with somatic cell counts, low-density lipoprotein cholesterol and oxidative stress (NEDIĆ et al., 2019). Equally PON-1 activity in cow plasma is closely related to reproductive performance (PEDRO et al., 2019). Such findings suggest that PON-1 plays an important role in lipid metabolism, thus there is a need for reliable immunoassays to assess plasma PON-1 levels for clinical and epidemiological purposes. PON-1 levels in plasma may be used as a specific marker for FL diagnosis (FARID et al., 2013), and similarly some studies have shown that PON-1, glucose (GLU), aminotransferase (AST), and non-esterified fatty acid (NEFA) levels may be used as indicators to predict FL risk in dairy cows (YIZHAO et al., 2018).

Currently, there is a lack of adequate clinical detection methods to predict quickly whether a cow has the risk of developing FL. In this study, we developed a monoclonal and polyclonal antibody for PON-1 in dairy cows, and established a PON1 double-antibody sandwich ELISA method. We implemented a clinical study to investigate clinical indications for dairy cows with FL.

\section{Materials and methods}

Experimental animals. All animal experiments complied with ARRIVE guidelines. All the animals were cared for in accordance with the principles of Heilongjiang Bayi Agricultural University (Number: 20180109-6). We used four adult male rabbits (Jilin University Experimental Animal Center, certificate number: 4200030000059), and mouse myeloma SP2/0 cells were provided by the Bacterial Laboratory, Zoonosis Institute, Jilin University China. Twenty-six head of Holstein cows, with similar body condition, were randomly selected from a free-feeding intensive dairy cow farm in Heilongjiang, China, at 14-21 days postpartum. All the cows were of similar age, with no other diseases.

Prokaryotic expression of bovine PON-1. The gene sequence for bovine PON-1 (XP616349) was optimized using the Escherichia coli preference codon program (http//www.jcat.de/start.jsp, host organism: E. coli strain (K12). The target gene was synthesized according to the optimized gene sequence, and cloned into a PUC57 plasmid (Jinweizhi Biotechnology Co., Ltd, China). The target gene was excised from this plasmid and inserted into the PET-28a plasmid, via NcoI/ XhoI restriction enzyme sites. The plasmid was transformed into competent cells and grown overnight in Luria Bertani broth at $37^{\circ} \mathrm{C}$ with shaking. The next day the culture was expanded, and when an $\mathrm{OD}_{600 \mathrm{~nm}}$ of 0.6 was reached, protein expression was induced by IPTG (the ratio of IPTG to bacterial suspension was $1: 1,000)$. The expressed protein was separated and purified from the gel, and identified by SDS-PAGE.

Preparation of a monoclonal antibody against the bovine PON-1 recombinant protein. Recombinant bovine $\mathrm{PON}-1$ protein was emulsified (1:1) in Freund's complete adjuvant at $4{ }^{\circ} \mathrm{C}$, and injected into test mice, through the foot pad and groin. Approximately $150 \mu \mathrm{g}$ of $\mathrm{PON}-1$ protein was injected into each mouse. SPF Balb/c female mice $(\mathrm{n}=10$ Jilin University experiment; Animal Center, Certificate No. 4200030000026) were boosted with recombinant bovine PON-1 protein in Freund's incomplete adjuvant every other week until week 4 after immunization. Finally, the mice were directly injected with PON-1 protein for booster immunization. Mouse lymphocytes are hybridized to SP2 cells. Positive hybridoma cells were screened by ELISA, employing a microtiter plate coated with $10 \mu \mathrm{g} / \mathrm{mL}$ purified bovine PON1. After three days, and after repeat cloning by limiting dilution techniques, positive hybridoma cells were cloned. After cloning, cells capable of secreting PON-1 antibody were obtained.

Positive hybridoma cells were injected into the peritoneal cavity of Balb/C mice at a rate of $5 \times 10^{5}$ cells $/ 0.2 \mathrm{~mL}$, per mouse. The peritoneal effusion 
was collected. Mice ascites were purified using a Hi Trap Protein G HP (GE, CT, USA) affinity column on an protein purification system (AKTA, GE, CT, USA). The purified monoclonal antibody was used as an incubation antibody for western blotting. This was performed according to a conventional method (REID et al., 1986). For western blotting, a human plasma/plasma high abundance protein kit (Merck \& Co Inc, NY, USA) was used to remove highly abundant proteins from the bovine plasma samples. The western blot was performed on the same gel, approximately $5 \mu \mathrm{L}$ of bovine plasma and PON-1 protein $(15 \mu \mathrm{L})$ were added to the four wells, and the primary antibody used for incubation was the PON-1 monoclonal antibody obtained by experiment. The secondary antibody was a rabbit anti-mouse IgG.

Preparation of rabbit anti-PON1 polyclonal antiserum. Emulsification was performed by adding $1 \mathrm{~mL}$ recombinant bovine $\mathrm{PON}-1$ protein to the same volume of Freund's complete adjuvant. Test rabbits were injected with multiple injections under the skin. After 14 days, a second immunization step was performed by reconstituting $1 \mathrm{~mL}$ bovine PON-1 protein and an equal volume of Freund's incomplete adjuvant. After 10 days, a third and fourth immunization were performed. Recombinant bovine PON-1 protein was injected directly after 10 days. After seven days immunization, blood was collected. The blood titer was determined by ELISA, using a microtiter plate coated with 10 $\mu \mathrm{g} / \mathrm{mL}$ purified bovine PON-1. The polyclonal antibody was purified using a Hi Trap Protein G HP on an affinity AKTA purification system (GE).

Establishment of double-antibody sandwich ELISA for PON-1. The monoclonal antibody was used as the detection antibody, the purified polyclonal antibody was used as the capture antibody, and the horseradish-labeled goat anti-mouse IgG was used as the enzyme-labeled secondary antibody.

ELISA plates were coated with different concentrations of polyclonal antibody (PBS: polyclonal antibody $=1: 100,1: 200,1: 400$, $1: 800,1: 16,000,1: 32,000,1: 64,000,1: 12,800)$ or monoclonal antibody $(0.2 \mathrm{mg} / \mathrm{mL}, 0.4 \mathrm{mg} / \mathrm{mL}, 0.8$ $\mathrm{mg} / \mathrm{mL}, 1.6 \mathrm{mg} / \mathrm{mL}, 3.2 \mathrm{mg} / \mathrm{mL}, 6.4 \mathrm{mg} / \mathrm{mL}$ ). Next, we determined the optimal working concentrations of the monoclonal and polyclonal antibodies based on $\mathrm{P} / \mathrm{N}$ (Positive control / Negative control) values.
The ELISA procedure was conducted as follows:

(1) The coating solution $\left(\mathrm{Na}_{2} \mathrm{CO}_{3} 1.59 \mathrm{~g} / \mathrm{L}\right.$ $+\mathrm{NaHCO}_{3} 2.93 \mathrm{~g} / \mathrm{L}$ ) and the polyclonal antibody were diluted 1:800, added to each well, and placed at $4{ }^{\circ} \mathrm{C}$ for $12 \mathrm{~h}$.

(2) The coating solution was discarded and 200 $\mu \mathrm{L} 1 \times$ PBST (Phosphate Tween Buffer) was added to each well. The plate was washed by shaking at $60 \mathrm{~s} / 500 \mathrm{rpm}$. After this, it was patted dry and this was repeated twice for 1.5 min each time.

(3) A total of $200 \mu \mathrm{L} 5 \%$ skim milk powder was added to each well for $2 \mathrm{~h}$ at $37^{\circ} \mathrm{C}$.

(4) The blocking solution was discarded and step 2 repeated.

(5) The bovine plasma to be tested was added to each well and blocked at $37^{\circ}$ for $2 \mathrm{~h}$.

(6) After this period, the plasma was discarded and step 2 repeated.

(7) In total, $100 \mu \mathrm{L}$ of $0.8 \mathrm{mg} / \mathrm{mL}$ monoclonal antibody was added to each well. Plates were incubated at $37^{\circ} \mathrm{C}$ for $2 \mathrm{~h}$.

(8) The antibody was discarded and step 2 repeated.

(9) To each well, $100 \mu \mathrm{L}$ rabbit anti-mouse IgG (PBS: rabbit anti-mouse $\mathrm{IgG}=1: 4,000$ ) was added at $37^{\circ} \mathrm{C}$ for $2 \mathrm{~h}$.

(10) To each well, $50 \mu \mathrm{L} \quad$ OPD (O-phenylenediamine) chromogenic solution was added and the plate incubated for $10 \mathrm{~min}$ in the dark, at $37^{\circ} \mathrm{C}$. Finally, $50 \mu \mathrm{L}$ stop solution $(88.9 \mathrm{~mL}$ deionized water $+11.1 \mathrm{~mL}$ $\mathrm{H}_{2} \mathrm{SO}_{4}$ was added to each well.

(11) The plate was read immediately on a microplate reader at $\mathrm{OD}_{450 \mathrm{~nm}}$.

ELISA quantitative detection limits. PON-1 was diluted to different concentrations as the sample, according to the optimal working conditions determined above (protein concentration: $12 \mathrm{ng} / \mathrm{mL}$, $24 \mathrm{ng} / \mathrm{mL}, 48 \mathrm{ng} / \mathrm{mL}, 90 \mathrm{ng} / \mathrm{mL}, 190 \mathrm{ng} / \mathrm{mL}, 390 \mathrm{ng} /$ $\mathrm{mL}, 780 \mathrm{ng} / \mathrm{mL}, 1,562.5 \mathrm{ng} / \mathrm{mL}, 3,125 \mathrm{ng} / \mathrm{mL}, 6,250$ $\mathrm{ng} / \mathrm{mL}, 12,500 \mathrm{ng} / \mathrm{mL}$ and $25,000 \mathrm{ng} / \mathrm{mL}$ ). Three parallel replicate test wells were performed for each concentration. Quantitative limits for this method were derived on the basis of these experimental results. A regression equation for the ELISA and the standard curve were established. Five batches 
of $780 \mathrm{ng} / \mathrm{mL}$ recombinant bovine PON-1 protein were used as standards. Five standard samples were detected by the bovine PON-1 double antibody sandwich ELISA method for spike recovery tests, and the recovery rate was determined according to the formula $=[(\mathrm{C}$ actual detected $) / \mathrm{C}($ standard $)] \times$ $100 \%$ detection standard recovery rate.

Clinical applications of the PON-1 ELISA. A liver puncture was performed on cows at $10 \mathrm{~cm}$ above the $11^{\text {th }}$ and $12^{\text {th }}$ ribs, between the cow's hip and right elbow. Two $g$ of liver tissue sample was collected. Samples were rapidly frozen in liquid nitrogen and stored at $-80{ }^{\circ} \mathrm{C}$. Liver $\mathrm{TG}$ (Triglyceride) was extracted using hexane and isopropanol, according to NEDIĆ et al., (2019). TG levels were determined using TG test kits (BIOSIO, Beijing, China).

\section{Results}

Prokaryotic expression of PON-1. Inducible bacterial expression by IPTG generated a $43 \mathrm{kDa}$ protein by SDS-PAGE electrophoresis (Fig. 1).

The PON-1 protein was expressed in inclusion bodies (Fig. 2). Protein purity was also verified by SDS-PAGE (Fig. 3).

There was only one band at the same position as the target protein $(43 \sim \mathrm{kDa})$, proving that the protein purification method was effective.

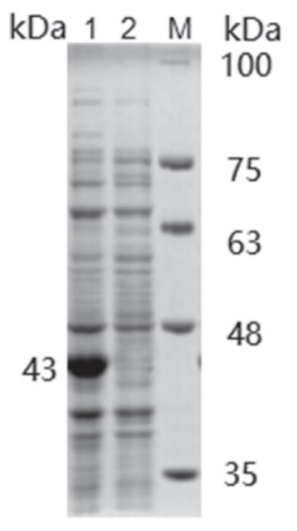

Fig. 1. Electrophoresis of protein expression. 1, induced bacteria; 2, negative control; $\mathrm{M}$, marker.
Test cows were divided into a healthy group $(\mathrm{n}=$ $13, \mathrm{C})$ and a FL group $(\mathrm{n}=13, \mathrm{FL})$ according to the standard of 5\% liver TG (wet weight basis).

PON-1 double-antibody sandwich ELISA was used to determine plasma PON-1 levels in the FL and C groups. NEFA and AST were detected using a biochemical analyzer (HITACHI, ES-480, Shanghai, China) and the relevant kits (BIOSINO, Beijing, China).

Statistical analysis. All data were statistically analyzed using IBM SPSS 19.0, and subjected to means analysis. Independent sample $t$-tests were performed between the experimental and control groups. Correlation analyses of the results from each group were analyzed by the Pearson's correlation coefficient method, and diagnostic effects and risk warning boundary values were analyzed by ROC.

Monoclonal antibodies. The positive rate of the cell after the first clone was $83.9 \%$, the positive rate of the cell after the second clone was $86.5 \%$, the positive rate of the cell after the third clone was $92.2 \%$, and the positive rate of the cell after the fourth clone was $98.6 \%$. After four times of cloning, cells secreting anti-bovine PON-1 protein were obtained. The monoclonal antibody was purified by the AKTA purification system, and the purified monoclonal antibody was subjected to SDS-PAGE. The results showed that the purified monoclonal antibody against the bovine $\mathrm{PON}-1$ protein had been generated (Fig. 4).

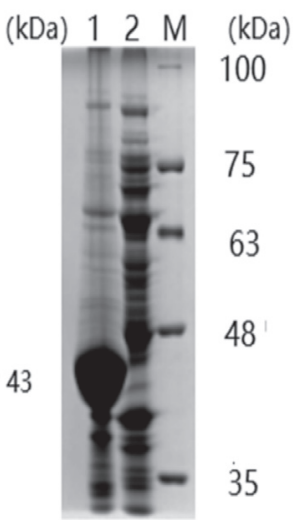

Fig. 2. Electrophoresis map of protein expression.1, inclusion body; 2, supernatant; $\mathrm{M}$, marker. 


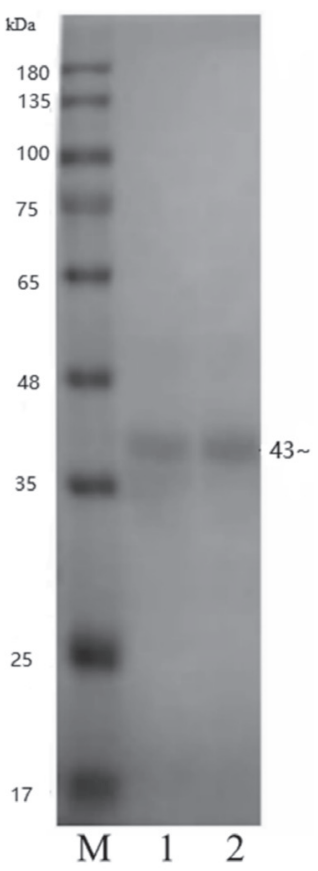

Fig. 3. SDS-PAGE validation map of induced proteins.1, PON-1protein; 2, PON-1protein; M, marker

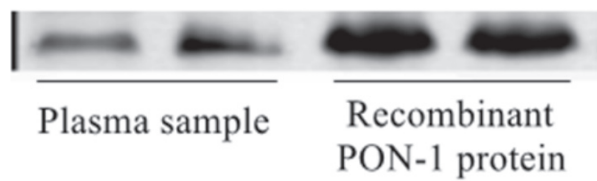

Fig. 5. Western blot of monoclonal antibody, to verify whether the monoclonal antibody can bind to the western blot experiment in bovine plasma. The antibody secreted by cells recognized endogenous bovine PON-1 protein.

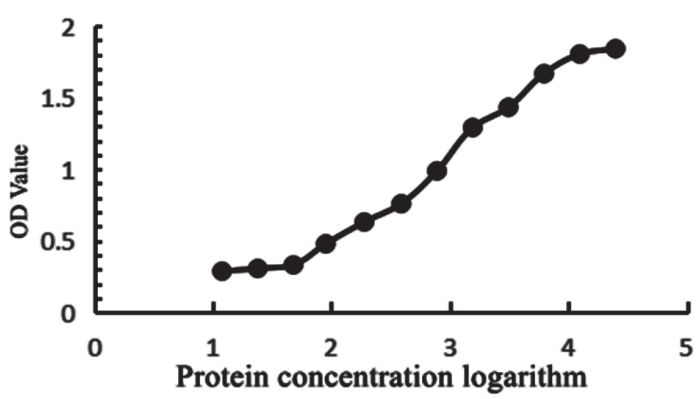

Fig. 7. Curves from the different concentration of proteins. The log of the OD and the protein concentration were plotted against each other to derive the lowest detection limit from the ELISA standard curve.

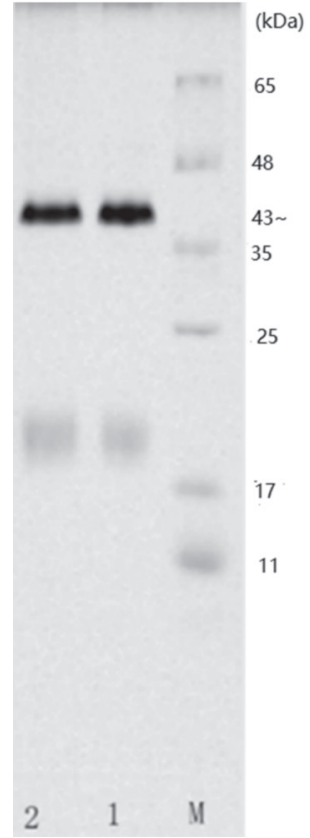

Fig. 4. Monoclonal antibody band in SDS-PAGE. M: marker; 1. mouse 1 ascites; 2 . mouse 2 ascites.

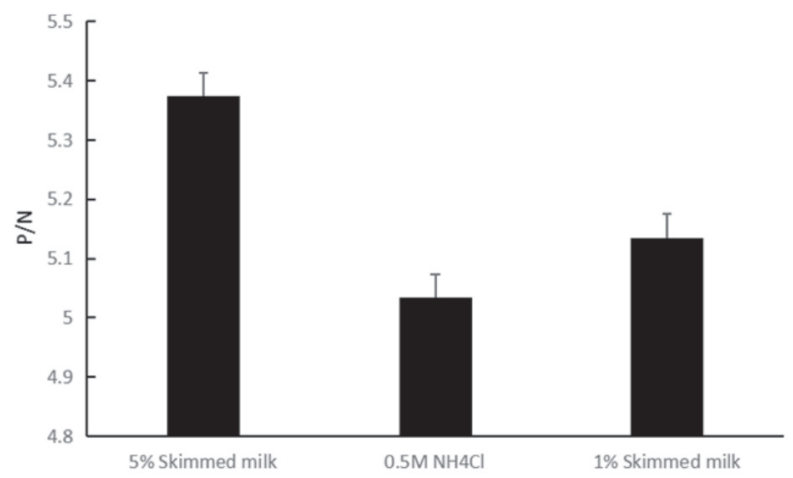

Fig. 6. Optimal choice of blocking solution.

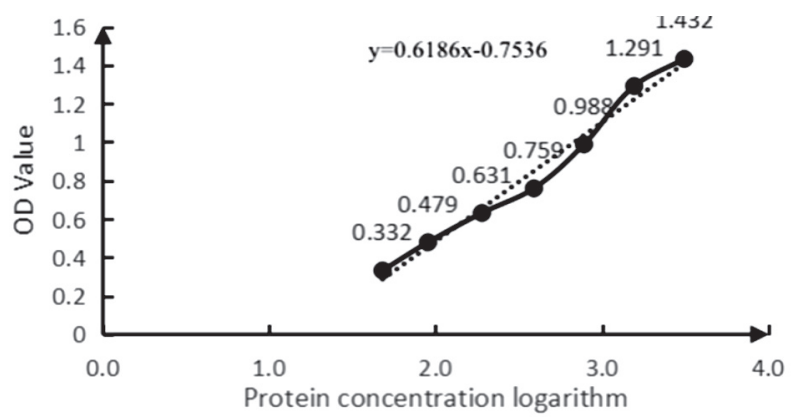

Fig. 8. ELISA standard curve, the quantitative limit of the method was $90 \mathrm{ng} / \mathrm{mL}$. The standard curve equation was $\mathrm{y}=0.6186 \mathrm{x}-0.7536(\mathrm{R} 2=0.9813)$. 
Table 1. Rabbit polyclonal plasma titres

\begin{tabular}{|l|c|c|c|c|c|c|}
\hline Dilution factor & $1: 1,000$ & $1: 2,000$ & $1: 4,000$ & $1: 8,000$ & $1: 16,000$ & $1: 32,000$ \\
\hline No. 1 rabbit P/N & 2.939 & 3.894 & 3.005 & 2.614 & 2.271 & 1.502 \\
\hline No. 2 rabbit P/N & 4.854 & 4.796 & 3.194 & 2.771 & 2.251 & 1.719 \\
\hline
\end{tabular}

Table 2. Level of basic information and blood biochemical parameters

\begin{tabular}{|l|c|c|c|}
\hline Parameters & $\begin{array}{c}\text { Control group } \\
(\mathrm{n}=13)\end{array}$ & $\begin{array}{c}\text { Fatty liver group } \\
(\mathrm{n}=13)\end{array}$ & $\begin{array}{c}\text { Significant } \\
(\mathrm{P})\end{array}$ \\
\hline Liver TG $(\%$ wet weight) & $2.66 \pm 0.81$ & $10.82 \pm 4.91$ & 0.00 \\
\hline Years & $3.17 \pm 1.04$ & $3.21 \pm 1.06$ & 0.741 \\
\hline Milk yield (kg/day) & $33.91 \pm 11.82$ & $33.15 \pm 9.28$ & 0.809 \\
\hline Body Condition Score & $3.57 \pm 0.25$ & $3.26 \pm 0.31$ & 0.102 \\
\hline AST (U/L) & $85.19 \pm 19.02$ & $162.40 \pm 60.96$ & 0.001 \\
\hline NEFA (mmol/L) & $0.63 \pm 0.21$ & $0.98 \pm 0.56$ & 0.003 \\
\hline PON-1 $(\mathrm{ng} / \mathrm{mL})$ & $2097.34 \pm 130.51$ & $1891.91 \pm 103.82$ & 0.004 \\
\hline
\end{tabular}

$\mathrm{P}=0.00$ is highly significant, Liver TG is liver triglyceride (\% wet weight), AST is aspartate aminotransferase, and NEFA is free fatty acid.

Table 3. Correlation between PON-1 and other indicators in dairy cows

\begin{tabular}{|l|c|}
\hline Parameters & PON-1 \\
\hline PON-1 & 1 \\
\hline Liver TG (\% wet weight) & $-0.60^{* *}$ \\
\hline AST & $-0.50^{*}$ \\
\hline NEFA & $-0.61^{* *}$ \\
\hline
\end{tabular}

$* \mathrm{P}<0.05 . * * \mathrm{P}<0.01$, Liver TG is liver triglyceride (\% wet weight), AST is aspartate aminotransferase and NEFA is free fatty acid.

Table 4. Hosmer-Lemeshow test

\begin{tabular}{|l|c|c|c|}
\hline Step & Bangla & df & Sig. \\
\hline 1 & 4.841 & 8 & 0.774 \\
\hline
\end{tabular}

The $\mathrm{df}$ is the degree of freedom, sig is significance

Table 5. Cutoff point, sensitivity, specificity, NRV, PPV, +LR, -LR and AUC of ROC

\begin{tabular}{|l|c|c|c|c|c|c|c|c|}
\hline Parameter & Cut off value & $\begin{array}{c}\text { Sensitivity } \\
(\%)\end{array}$ & $\begin{array}{c}\text { Specificity } \\
(\%)\end{array}$ & $\begin{array}{c}\text { NPV } \\
(\%)\end{array}$ & $\begin{array}{c}\text { PPV } \\
(\%)\end{array}$ & +LR & -LR & AUC \\
\hline PON-1 & 61.87 & 91.9 & 94.87 & 64.51 & 7.96 & 0.00 & 0.84 & 91.9 \\
\hline
\end{tabular}

NPV is negative predictive value, PPV is positive predictive value, + LR positive still ratio, -LR negative still ratio, ROC receiver operating characteristic curve, AUC is the area under the ROC curve 


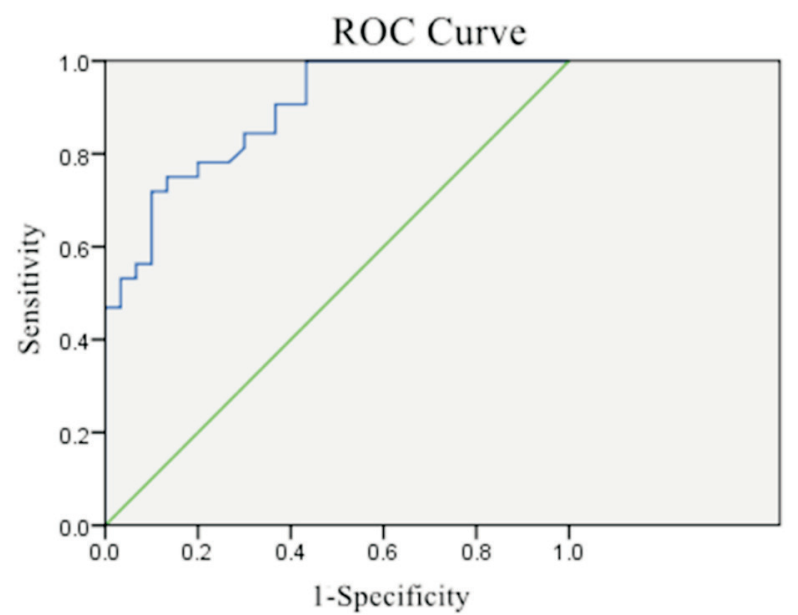

Fig. 9. ROC curve of PON-1 on fatty liver in dairy cows

To verify whether the monoclonal antibody could bind to the western blot experiment in bovine plasma, Fig. 5, the antibody secreted by cells recognized the endogenous bovine PON-1 protein. In this figure, from left to right, 1 and 2 wells were loaded with natural bovine plasma, and 3 and 4 wells were loaded with recombinant bovine PON-1 protein.

According to Image $\mathrm{J}$ analysis, the 1.2 well gray scale was significantly lower than 3.4 wells because PON-1 in natural bovine plasma is lower than the recombinant $\mathrm{PON}-1$ protein concentrations used in the experiment. However, plasma in 1.2 wells recognized the monoclonal antibodies.

Polyclonal antibodies. The polyclonal antibody titer was detected by an ELISA method using recombinant PON-1 protein. As shown (Table 1), when this antibody was diluted to $1: 1,600$ in PBS, $\mathrm{P} / \mathrm{N}$ (negative well $\mathrm{OD}$ value/positive well OD value) $\geq 2.0$. These data suggested these antibodies could be used in subsequent experiments

ELISA standardization. As a result, it was found that the optimum coating concentration was: 1:800 dilution of the polyclonal antibody and PBS, the concentration of the monoclonal antibody was 0.8 $\mathrm{mg} / \mathrm{mL}$. The optimal working time of the ELISA was determined on the basis of the $\mathrm{P} / \mathrm{N}$ value. The coating procedure was performed overnight at $4{ }^{\circ} \mathrm{C}$. The $\mathrm{P} / \mathrm{N}$ value was as high as 5.46 at $37{ }^{\circ} \mathrm{C}$, at 2 $\mathrm{h}$. The $\mathrm{P} / \mathrm{N}$ value was highest when the blocking solution was 5\% skimmed milk (Fig. 6.)
The log of the OD and the protein concentration were plotted against each other to derive the lowest detection limit from the ELISA standard curve. As shown (Fig. 7), a linear trend began at $90 \mathrm{ng} / \mathrm{mL}$. The curve exhibited a linear pattern when the protein concentration was between $90 \mathrm{ng} / \mathrm{mL}$ and 3,125 ng/ mL. As shown (Fig. 8), the quantitative lower limit of the method was $90 \mathrm{ng} / \mathrm{mL}$. The standard curve equation was $\mathrm{y}=0.6186 \mathrm{x}-0.7536\left(\mathrm{R}^{2}=0.9813\right)$.

Five batches of $780 \mathrm{ng} / \mathrm{mL}$ recombinant bovine PON-1 protein were used as standard. The test results of the samples were $763.6 \mathrm{ng} / \mathrm{mL}, 762.7 \mathrm{ng} /$ $\mathrm{mL}, 782.1 \mathrm{ng} / \mathrm{mL}, 750.6 \mathrm{ng} / \mathrm{mL}$, and $762 \mathrm{ng} / \mathrm{mL}$, and the recovery rate was $97.97 \%$.

PON-1 ELISA clinical application test. Information on study dairy cows is shown (Table $2)$. The liver TG concentration in FL cows was significantly greater $(\mathrm{P}<0.01)$ than in the $\mathrm{C}$ cows. NEFA and AST plasma levels in the FL group were significantly higher than in the $\mathrm{C}$ group $(\mathrm{P}<0.01)$. The ELISA results showed that plasma PON-1 levels in the FL group were significantly lower than in the $\mathrm{C}$ group $(\mathrm{P}<0.01)$.

Early warning indicators of FL in dairy cows. According to the Pearson's correlation coefficient between PON-1 and other indicators (Table 3), PON-1 levels were positively correlated with the content of the liver TG concentration, AST and NEFA. Data from Hosmer and Lemeshow tests showed that the model chi-square was 4.841 , based on significance (0.05) and degrees of freedom (df) (Table 4). The chi-square threshold was calculated using CHIINV (significance value, degree of freedom) in EXCEL. The settlement was CHIINV $(0.05,8)=15.507$, and the chi-square was $<$ the chi square threshold. A binary logistic regression model was established using SPSS analysis software to simulate the results of a self-built ELISA. Hosmer and Lemeshow results are shown in Table 5. The PON-1 cutoff point, sensitivity, specificity, NRV (negative predictive value), PPV (positive predictive value), LR (likelihood ratio), and AUC (area under the curve) can be seen. Fig. 9 shows the ROC curve of PON-1 protein in dairy cows with FL. The AUC was 91.9. According to Table 5 and Fig. 9, plasma PON-1 levels in dairy cows could be used as a warning indicator for FL risk. The warning value was $61.87 \mathrm{nmol} / \mathrm{L}(2,097.34 \mathrm{ng} / \mathrm{mL})$. 


\section{Discussion}

FL is a common serious metabolic disease in the perinatal period. The costs associated with FL include a drop in milk yield and the generation of other diseases, such as sputum and postpartum anoestrus (YU-XI et al., 2019). The condition has brought huge economic losses to the dairy industry (PADILLA et al., 2015). Our aim was to establish a method for the early detection of FL in dairy cows, and to reduce the economic losses caused by FL. The probability of FL occurring can be predicted after delivery. CAO et al., (2017), and FARID et al., (2013) showed that plasma PON-1 levels could be used as an early warning indicator of FL in dairy cows. Therefore, we developed an ELISA that could detect PON-1 levels in dairy cow plasma. In relation to other commercially available PON1 kits, we selected the sandwich monoclonal and polyclonal antibody method to recognize bovine PON-1. This improved detection specificity and sensitivity. This study not only established an ELISA method, but also evaluated specificity, sensitivity and a predictive value for assessing FL in dairy cows.

At present, one particular detection method for PON-1 is the spectrophotometric approach to determine enzymatic activity, and the other is PON-1 determination (COSTA et al., 2005) by immunological assay, using specific antibodies. A commonly used detection method is to measure PON-1 activity indirectly by measuring PON1's ability to hydrolyze corresponding substrates (phosphorus, non-phosphoaryl, dihydrocoumarin, etc.) using a spectrophotometer. The method is cheap and simple. However, there are disadvantages; the different hydrolysis substrates used and the associated measurement conditions make it difficult to compare PON-1 activities from different experiments. Similarly, the results may be inconsistent due to different analysis procedures, or differences in hydrolysis substrates, and the PON-1 activity is related to its polymorphism. The method's main drawback is that most PON1 hydrolyzed substrates contain different degrees of toxicity, meaning detection is problematic (LI et al., 2000). To this end, immunological methods using specific antibodies can be used. They avoid spectrophotometers in determining hydrolyzed substrates, and they are suitable for clinical use. The ELISA method established in this study is mainly applicable to clinical use, and can quickly diagnose whether a cow has FL. Improper preservation of serum during clinical operations will lead to the degradation of enzyme activity. When compared with PON-1 activity determination, the protein detection method established here is more suitable for clinical applications at dairy cow farms. A sandwich ELISA for bovine plasma PON-1 concentration was established using monoclonal and polyclonal antibodies. The specificity of monoclonal antibodies was confirmed by western blotting. Monoclonal antibodies reacted with a single protein of approximately $43 \mathrm{kDa}$, which was the same as that previously reported for bovine plasma PON-1 (ERZENGIN et al., 2014). In the ELISA experiment, to reduce experimental error, we ensured that all solutions were prepared in the same batch, and the $\mathrm{pH}$ was predetermined to ensure assay stability. Our ELISA used a multiantibody coated ELISA plate and a monoclonal antibody as the detection antibody. A commonly used blocking solution is BSA (Bovine serum albumin). We considered that the antibody used in this test is bovine PON-1 protein. To prevent cross-reaction between BSA and bovine PON-1, BSA was not used as a blocking solution in our test conditions. Different concentrations of standards, ranging from $12 \mathrm{ng} / \mathrm{mL}-25000 \mathrm{ng} / \mathrm{mL}$ were detected by ELISA. The OD was plotted against the logarithm of the protein concentration. The results showed that the curve began to show a linear trend when the standard concentration was between 90 $\mathrm{ng} / \mathrm{mL}$ and $31250 \mathrm{ng} / \mathrm{mL}$. Therefore, the detection concentration range of the ELISA was set at $90 \mathrm{ng} /$ $\mathrm{mL}$ to $3125 \mathrm{ng} / \mathrm{mL}$.

We showed that plasma PON-1 was associated with FL in cows. Perinatal dairy cows have increased nutritional needs and insufficient dry matter intake, leading to a negative energy balance that initiates fat mobilization. Fat mobilization produces a large amount of fatty acids that enter the liver, and this is the main reason for the high incidence of FL in perinatal dairy cows (DRACKLEY et al., 2001). Cows with FL produce high levels of 
ROS causing oxidative stress (SUN et al., 2019). FARID et al., (2013) found that ROS inhibits PON1 synthesis during oxidative stress in the liver, and ultimately leads to a decrease in PON-1 in the body. Furthermore, PON-1 levels in plasma can be used as a detection index for dairy cows with FL, which is consistent with our experimental results. Our ELISA was used to detect PON-1 in the plasma of two groups of experimental cows, and a binary logistic regression model was established. ROC analysis confirmed that our ELISA predicted FL in dairy cows. This was consistent with FARID et al., (2013) and CAO et al., (2017) who reported that plasma PON-1 can be used as a warning index for cow FL (WALSH et al., 2007). PON-1 levels in the FL group were significantly lower than levels in the $\mathrm{C}$ group. This was consistent with data from previous studies (FARID et al., 2013; CAO et al., 2017), and demonstrated that our PON-1 ELISA may be used in clinical trials. The risk index of PON-1 for FL was derived by ROC analysis, and revealed a correlation between PON-1 and FL. The warning value was: $61.87 \mathrm{mmol} / \mathrm{L}(2097.34 \mathrm{ng} / \mathrm{mL})$.

\section{Conclusions}

In this study, a novel ELISA was successfully constructed by preparing monoclonal and polyclonal antibodies against bovine PON-1. PON-1 levels in the plasma of dairy cows was detected by ELISA, showing that PON-1 was highly correlated with FL. Our data demonstrated that our ELISA predicted risk factors for dairy cows with FL.

\section{Acknowledgements}

This study was supported by the National Natural Science Foundation of China (Grant No: 31772804), by the National Key R\&D Program of China (Grant No. 2017YFD0502200) and Postgraduate Innovation Project of Heilongjiang Bayi Agricultural University (No.YJSCX2019-Z02). We thank the Business Management Department, SRUC South and West Faculty, and International Science Editing (http://www. internationalscienceediting.com) for editing this manuscript.

\section{References}

CAO, Y., J. ZHANG, W. YANG, C. XIA, H. Y. ZHANG, Y. H. WANG (2017): Predictive value of plasma parameters in the risk of postpartum ketosis in dairy cows. J. Vet. Res. 61, 112-116.

DOI: $10.1515 /$ jvetres-2017-0011
COstA, L. G., TB. COLE, A. VITALONE (2005): Measurement of paraoxonase (PON-1) status as a potential biomarker of susceptibility to organophosphate toxicity. Clinica Chimica Acta; International Journal of Clinical Chemistry 352, 37.

DOI: 10.1016/j.cccn.2004.09.019

DU, X., Z. Y. ZHANG (2018): High concentrations of fatty acids and $\beta$-hydroxybutyrate impair the growth hormonemediated hepatic JAK2-STAT5 pathway in clinically ketotic cows. J. Dairy Sci. 101, 3476-3487.

DOI: $10.3168 /$ jds.2017-13234

DRACKLEY, J. K., T. R. OVERTON, G. N. DOUGLAS (2001): Adaptations of glucose and long-chain fatty acid metabolism in liver of dairy cows during the periparturient period. J. Dairy Sci. 84, 215-219.

DOI: $10.3168 /$ jds.S0022-0302(01)70204-4

ERZENGIN, M., D. DEMIR, M. ARSLAN (2014): Purification and characterization of paraoxonase 1 (PON1) from Swiss Black, Holstein, and Montofon bovines. Applied Bio. Bio. 173, 1597-1606.

DOI: $10.1007 / \mathrm{s} 12010-014-0931-1$

FARID, A. S., K. HONKAWA, E. M. FATH, N. NONAKA, Y. HORII (2013): Serum paraoxonase-1 as biomarker for improved diagnosis of fatty liver in dairy cows. BMC. Vet. Res. 9, 73.

DOI: $10.1186 / 1746-6148-9-73$

KULKA, M., J. BELTOWSKI, W. KLUCINSKI, M. ORLOWSKA, J. KOLODZIEJSKA, M. KLECZKOWSKI (2014): Serum paraoxonase-1 activity of dairy HolsteinFresian cows in different lactation stages preliminary study. Pol. J. Vet. Sci. 17, 143-147.

DOI: $10.2478 /$ pjvs-2014-0019

LI, W. F., L. G. COSTA, R. J. RICHTER, T. HAGEN, D. M. SHIH, A. TWARD, A. J. LUSIS, C. E. FURLONG (2000): Catalytic efficiency determines the in-vivo efficacy of PON-1 for detoxifying organophosphorus compounds. Pharmacogenetics 10, 767-779.

DOI: 10.1097/00008571-200012000-00002

MELENDEZ, P., F. WILLIAMS, P. PINEDO, D. MANRIQUEZ, S. G. MOORE, M. C. LUCY, P. PITHUA, S. POOK (2018): Technical note: Evaluation of fine needle aspiration cytology for the diagnosis of fatty liver in dairy cattle. J. Dairy Sci. 101, 1167-1171.

DOI: $10.3168 /$ jds.2017-13346

MIYAMOTO, T., Y. TAKAHASHI, T. OOHASHI (2005): Bovine paraoxonase 1 activities in serum and distribution in lipoproteins. J. Vet. Med. Sci. 67, 243-248.

DOI: $10.1292 /$ jvms.67.243

MOTTA, S., C. LETELLIER, M. ROPERT (2009): Protecting effect of vitamin E supplementation on submaximal exercise-induced oxidative stress in sedentary dogs as assessed by erythrocyte membrane fluidity and paraoxonase-1 activity. Vet. J. 181, 288.

DOI: 10.1016/j.tvj1.2008.03.013 
NEDIĆ, S., S. VAKANJAC, M. SAMARDŽIJA, S. BOROZAN (2019): Paraoxonase 1 in bovine milk and blood as marker of subclinical mastitis caused by Staphylococcus aureus. Res. Vet. Sci. 125, 323-332.

DOI: 10.1016/j.rvsc.2019.07.016

PEDRO, A. S. S., W. R. BUTLER, S. E. LACOUNT, T. R. OVERTON, C. B. CARLOS, S. AUGUSTO (2019) Polymorphisms in the anti-oxidant paraoxonase-1 (PON1) gene associated with fertility of postpartum dairy cows. Theriogenology 125, 302-309.

DOI: $10.1016 /$ j.theriogenology.2018.11.024

PADILlA, L., K. I. SHIBANO, INOUE, T. TOHRU, H. TOHRU, (2015): Plasma vitamin C concentration is not related to the incidence of ketosis in dairy cows during the early lactation period. Vet. Med. Sci. 67, 883-886.

DOI: 10.1292/jvms.67.883

RICHTER, RJ., G. P. JARVICK, C. E. FURLONG (2009): Paraoxonase 1 (PON1) status and substrate hydrolysis. Toxicol. Appl. Pharmacol. 235, 1-9.

DOI: 10.1016/j.taap.2008.11.001

REID, I. M., C. J. ROBERT, R. J. TREACHER, L. A. WILLIAMS (1986): Effect of body condition at calving on tissue mobilization, development of fatty liver and blood chemistry of dairy cows. Animal Sci. 43, 7-15.

DOI: $10.1017 / \mathrm{S} 0003356100018298$

SUN, X., H. JIA, Q. XU, C. ZHAO, C. XU (2019): Lycopene alleviates H2O2-induced oxidative stress, inflammation and apoptosis in bovine mammary epithelial cells via the NFE2L2 signaling pathway. Food Funct. 10, 6276 - 6285.

DOI: $10.1039 /$ C9FO01922G
TVARIJONAVICIUTE, A., J. J. CERON, S. L. HOLDEN, P. J. MORRIS, V. BIOURGE, A. J. GERMAN (2005): Effects of weight loss in obese cats on biochemical analytes related to inflammation and glucose homeostasis. Domest. Anim. Endocrinol. 42, 129-141.

DOI: $10.1016 /$ j.domaniend.2011.10.003

VALERIA, S., M. D'AVENIA, A. ARGENTIERO, C. FELICI, F. M. RIZZO, G. D. PERGOLA, F SILVESTRIS (2016): Obesity and breast cancer: molecular interconnections and potential clinical applications. Oncologist. 21, 404-417.

DOI: 10.1634/theoncologist.2015-0351

WALSH, R. B., J. S. WALTON, D. F. KELTON (2007): The effect of subclinical ketosis in early lactation on reproductive performance of postpartum dairy cows. J. Dairy Sci. 90, 2790-2796.

DOI: $10.3168 /$ jds.2006-560

YIZHAO, S., L. CHEN, WENZHU, Y. Z. WANG (2018): Exploration of serum sensitive biomarkers of fatty liver in dairy cows. Sci. Rep-US. 8, 13574.

DOI: $10.1038 / \mathrm{s} 41598-018-31845-0$

YU-XI, S., H. PAN, B. YUN-LONG, (2019): Plasma metabolic characterisation of dairy cows with inactive ovaries and estrus during the peak of lactation. J. Vet. Res. 63, 62-64.

DOI: $10.2478 /$ jvetres-2019-0047

Received: 14 April 2020

Accepted: 21 July 2020

ZHAO, C., Y. BAI, D. WANG, C. XIA: Uspostava sendvič ELISE testa za goveđi plazma PON-1 i njegova prediktivna vrijednost za masnu jetru u mliječnih krava. Vet. arhiv 91, 503-512, 2021.

\section{SAŽETAK}

Cilj ovog rada bio je unaprijediti kliničku dijagnostiku masne jetre (FL) u mliječnih krava upotrebom enzima paraoksonaze-1 (PON-1) kao indeksa za otkrivanje bolesti. Primijenjena je metoda prokariotske ekspresije kako bi se proizveo rekombinantni goveđi protein PON-1. Miševi su imunizirani ovim proteinom kako bi porizveli stanice hibridoma sa stabilnim izlučivanjem anti-PON-1. Stanice su injektirane u peritonealnu šupljinu miševa te je ascites pročišćen kako bi proizveo goveđa monoklonska protutijela PON-1. Tim su antigenom imunizirani kunići te je dobiveno poliklonsko antitijelo na goveđi PON-1. Upotrebom monoklonskih i poliklonskih antitijela uspostavljen je sendvič ELISA test dva sloja antitijela za plazmatski PON-1. Uzorci plazme prikupljeni su iz zdravih krava (n = 13) i krava s masnom jetrom $(\mathrm{n}=13)$, dok su razine plazmatskog PON-1 detektirane upotrebom PON-1 ELISA. Analizom ROC krivulje analizirane su korelacije između razina PON-1 i FL-a. Rezultati pokazuju da je idealna radna koncentracija monoklonskih protutijela bila $0,8 \mathrm{mg} / \mathrm{mL}$, a kvantitativno ograničenje detekcije $90 \mathrm{ng} / \mathrm{mL}$. Razine plazmatskog PON-1 bile su znakovito niže u krava s masnom jetrom u usporedbi sa zdravim životinjama. Zaključeno je da je PON-1 dobiven ELISA-om prediktor rizičnih čimbenika za masnu jetru u krava. Plazmatske razine PON-1 mogu poslužiti kao rani pokazatelj masne jetre, a kao upozoravajući indeks pokazala se koncentracija od $61,87 \mathrm{nmol} / \mathrm{L}$.

Ključne riječi: klinička primjena; ELISA; masna jetra; PON-1; ROC 